\title{
OUR DIVISION OF WORLD WAR WORK
}

As heretofore stated in the AnNals, our World War Division of the Iowa Historical, Memorial and Art Department set out to supplement the information which a mere roster affords of men who served from Iowa in the World War. It is to be presumed that the adjutant-general will in due time publish such roster, and that it will resemble rosters of Iowa soldiers in prior wars in that it will detail with accuracy the service of each Iowa man in uniform under the stars and stripes, but will not furnish information beyond the brief period of military service, although in the building of our state the subsequent civil life of each man and woman shall be worthy of public record.

We here set out a typical communication upon Iowa men in foreign service in the World War-men not in Iowa organizations, or even under the stars and stripes, but who contributed to the common cause none the less. Their status in the biographical sense is the same as that of their companions in arms who were never elsewhere than under American command.

\section{NAVY LEAGUE OF THE UNITED STATES \\ Department No. 6 \\ Box 2133 Middle City Station \\ Philadelphia, Pennsylvania \\ U. S. A.}

L. S. M. Robinson, Searetary

Edgar R. Harlan Esq., Curator.

November 22, 1925.

Historical Department of Iowa.

Dear Sir:

We are sending you eighteen more copies of war service records of men from your state who served, during the World War, in the armies and navies of the Allies, and we hope they will prove of value to you.

We will be very grateful for any similar war records with which you may at any time be able to furnish us. We would point out that our list is limited to those who were American citizens at the time of their crilistment; we do not include foreigners who were merely residents of this country, nor men born in the United States who had become naturalized abroad before 1914 .

We have underlined on the records any facts of especial interest, such as enlistment in the early days of the War, or the extreme youth or age of the soldier. 
While we believe that all the records which we are sending you are those of men who were American eitizens, yet we do not guarantee this, as some ignorant persons are rather vague as to their nationality. We have simply copied the facts supplied by the soldiers themselves. Our questionnaire forms contain the words "If naturalized give date and place of naturalization" and, to secure more explicit information, we have lately added the words, "Was he an American citizen at the time of enlistment?"

Wishing you all success in your task of preserving the memory of $\Lambda$ merican fighting men,

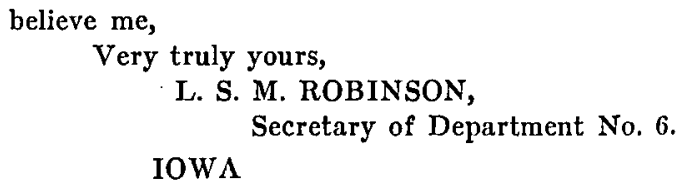

WOMERSLEY, W. M.

Home town: Sioux City, Iowa.

Born at Halifax, Yorkshire, March 8, 1890. Entered the United States

from Canada while an infant.

Became a naturalized American before November, 1916.

Enlisted at Chicago, Illinois.

The Duke of Wellington's West Riding Regiment, British Army.

Rank: private, No. 57153 .

Returned to the United States on S. S. "Orduna."

Worked for H. McIntyre's Iron Co., 521 Fifth Street, Sioux City.

Address: 216 9th Street, Sioux City, Iowa.

Buxton, William Henry.

Born at Des Moines, Iowa.

Enlisted at Chesterfield, Derbyshire, England.

218th Battalion, The Sherwood Foresters (Nottinghamshire and Derbyshire Regiment), British Army.

Rank: private, No. 77348 .

Served in France and Flanders.

Killed in action September 26, 1917.

Mtr.,FR, D.

Home town: Davenport, Iowa.

Born at Davenport, Iowa, November 2, 1888.

Enlisted in Scotland, February 27, 1915.

Royal Army Service Corps, British Army.

Rank: private, No. M/051065.

Returned to the United States on S. S. "Orduna," sailing from England June 7, 1919.

Address: Route 1, Box 126, Davenport, Iowa.

Joseph, Joseph Richapd.

Born in Iowa.

Enlisted in London, England. 
5th City of London Battalion (London Rifle Brigade), British Army. Rank: lance-corporal, No. 302390.

Scrved in France and Flanders.

Died of wounds March 25, 1918.

Franklin, Kellogo.

Born in Ames, Iowa, April 17, 1895.

25th Battalion Canadian (Nova Scotia) Infantry. Transferred to 2/28th Battalion, City of London Regiment (Artist's Rifles) British Army.

Transferred to the Royal Engineers, British Army.

Promoted from private in the Canadian Infantry to Corporal Artist's Rifles to Lieutenant Royal Engineers.

Rank: lieutenant.

Graduated from Yale, 1916.

Address: Yale Club; New York City.

Information furnished by brother, Curtis Franklin.

Birsey, B. C. Noe.

Home town: Charles City, Iowa.

Born in the United States.

Coldstream Guards, British Army.

Rank: lieutenant.

Information supplied by Guards Employment Society, London.

Moller, Arthur Appleby.

Home town: Sioux City, Iowa.

Born in the United States.

Grenadier Guards, British Army.

Rank: lieutenant.

Information supplied by Guards Employment Society, London.

WiLLIArrsos, JoHn.

Born at Cherate County, Kansas.

Enlisted at Cowdenheath, Fifeshire, Scotland.

Ist Battalion, 'The Black Watch (Royal Highlanders), British Army.

Killed in action in France or Flanders, May 9, 1915.

Carter, Lloyd Hawlex.

Home town: Ottumwa, Iowa.

Born at Ottumwa, Iowa.

Enlisted May 31, 1917, at Hamilton, Ontaria, Canada.

2nd Depot Regiment, Canadian Mounted Rifles. Shortly afterwards transferred to Royal Flying Corps, later Royal Air Force.

Promoted to non-commissioned flying instructor.

Killed in flying accident at Leaside near Toronto, Canada, February $28,1918$.

Buried at Ottumwa, Iowa, with full military honors.

Information furnished by Vernon Everett Bundy, c/o The Rev. D. IE.

Bundy, Trinidad, Colorado. 
Benwell, Eariest.

Son of Robert Wakefield Bedwell and Nevada Cromer.

Home town: Spring Hill, Iowa.

Born at Spring Hill, July 16, 1893.

Fnlisted March 2, 1916.

194th Battalion Canadian Infantry (Edmonton Highlanders).

Rank: private, No. 904599 .

Was recommended for the British Distinguished Conduct Medal by Australian officers at Wouverghen Woods in 1917, but never received it. Wounded $\Lambda$ pril 13,1918 , in the retreat from $\Lambda$ rmentieres.

'Took part in the following battles: Paschendaele, 1917; Messines, 1917; Amiens, 1918; Retreat from Armentieres, 1918.

Discharged February 24, 1919.

After enlistment, was sent to Edmonton, Alberta, for training, then to Sartec Camp, Calgary, Alberta, where he trained until December 4, 1916, when was sent overseas. Transferred to the 211th Battalion, Canadian Infantry (American Legion) October, 1916. L.eft England for France April 14, 1917. Was a dispatch writer in France. Wounded in leg April 13, 1918, and then invalided to England, sent to the Second Southern General Hospital at Bringham, England, July 24, sent to a hospital at Buxton, where he remained until October 18, when he was sent to Liverpool and invalided back to Canada October 31, 1918; arrived there on Armistice Day and sent to hospital at Edmonton, Alberta, where he remained until the date of his discharge. Was in liospital one year and a month, and had six operations.

\section{Harkins, John Cornetuus.}

Son of John Harkins and Jane Coyle.

Home town: Waukon, Iowa.

Born at Waukon, August, 1882.

Enlisted July 28, 1916.

27th Battalion, Canadian Infantry, Second Division.

Rank: private, No. 913684 .

Took part in the fighting from Vimy Ridge to Armistice Day.

Address: Anyox, P. O. Box 126, British Columbia, Canada.

Halverson, Melvin.

Son of Henry Halverson and Isabell Larson:

Born in Clay County, Iowa, March 5, 1899.

Enlisted February 22, 1916.

209th Battalion, Canadian Infantry; transferred to 103rd Battalion.

Rank: private, No. 252248.

I.ost his left leg except eight inches of thigh at Vimy Ridge.

Went to France in 1916.

Took part in the following battles: Somme, Vimy Ridge, Second battle of Ypres.

On February 11, 1922, he was accidently shot by a neighbor's boy with a 88 calibre revolver, shot through the abdomen, bullet lodged in the 
spine, operated on at the hospital at Medicine Hat, Alberta Hospital, but died February 13, 1922.

Buried at Hatten, Saskatchewan, Canada.

Next of kin: Henry Halverson, Kinkorth, Saskatchewan, Canada (father).

Weiliner, Ina Milton.

Son of Francis Welliner and Bertha Peterford.

Born at Lansing, Iowa.

Enlisted March 30, 1916.

175th Battalion, Canadian Infantry.

Rank: private, No. 696615.

Discharged July 13, 1919.

Address: Suffield, Alberta, Canada.

'Transferred to the Canadian Forestry Corps, February, 1917, with which he served in France.

Whienock, Jesse Hayes.

Son of Alfred Wheelock and ___ Emerson.

Home town: Algona, Iowa.

Born May 11, 1876.

Enlisted July 12, 1915.

No. 2 Platoon, A Company, 66th Battalion Canadian Infantry.

Rank: private, No. 100956.

Only got as far as England when he became ill and unfit for service in France, so was sent back to Canada.

Discharged November 11, 1916.

Address: Edmonton, Alberta, Canada.

Butcer, Johe Frascis.

Son of W. H. Bulger and Annie Anderson.

Born at Northwood, Worth County, Iowa.

Jinlisted January 6, 1915.

1st Battalion, Canadian Mounted Rifles.

lank: private, No. 108122.

Awarded the Distinguished Conduct Medal.

l.ost his left hand at Hooge, March 22, 1915.

Discharged January 14, 1917.

He was awarded the Distinguished Conduct Medal for picking up a live hand grenade and throwing it from the trench.

Adlress: Arrowwood, Alberta, Canada.

Y'rens, NiELS C.

Son of Nick Ytzen and I.ena Petersen.

Home town: Hampton, Iowa.

Born at Thornton, Iowa, November 22, 1892.

American citizen at time of enlistment.

Enlisted June 12, 1917.

Motor Transport Service, Royal Army Service Corps, British Army.

Rank: private No. M/408631.

Discharged March 31, 1920. 
Address: Hampton, Iowa.

Litroy, Earr Burtor.

Son of James Litton and Ella Case.

Home town: Fairfield, Iowa.

Born at Fairfield, January 5, 1893.

Enlisted March 22, 1915.

Royal Army Service Corps, 43rd Remount Squadron and General Headquarters Staff, British Army.

Promoted twice to sergeant and staff-sergeant; rank at time of discharge, private, No. R4/063381.

Discharged June 28, 1919.

Address: R. F. D. 5, Fairfield, Iowa.

Hull, Harry.

Son of Francis McClellan Hull and Mary Ellen Shroyer.

Home town: Oskaloosa, Iowa.

Born at Peoria, Iowa.

Enlisted January 22, 1917.

Inland Water Transport and Inland Waterways and Docks Section Royal Engineers, British Army.

Rank: sapper, No. 271902.

Served in France 1917-1918.

Discharged May 25, 1919.

Address: University Park, Iowa.

TWO INTERESTING CANES.

Two of the score of walking sticks in our collections have interesting origins and implications.

Of the two in mind, one was presented to us by Charles Mason Remey, son of Admiral George C. Remey. The mother of Charles Mason Remey was a daughter of Charles Mason, eminent early Iowa jurist and political leader of first rank in Washington, $D$. C., from 1850 to 1870 . This cane is not beautiful. The ferule is broken off and gone. But attached to the ivory head is a card in the writing of. Mr. Remey reading, "Walking Stick given to Charles Mason by Jefferson Davis. Cut from the Davis home estate."

The second cane was presented to us by Emerson Hough and to it is attached a card inscribed in the handwriting of Mr. Hough: "This cane was made from an Abraham Lincoln rail. Presented to Emerson Hough by his father-in-law, C. H. Chesebro, of Galesburg, Ill. It was given to Mr. Chesebro by Mr. Chapman, of Farmington, Ill., and is a Lincoln relic, or of his immediate day. E. H." 
Copyright of Annals of Iowa is the property of State of Iowa, by \& through the State Historical Society of Iowa and its content may not be copied or emailed to multiple sites or posted to a listserv without the copyright holder's express written permission. However, users may print, download, or email articles for individual use. 